Journal of Engineering and Applied Sciences 15 (4): 925-931, 2020

ISSN: $1816-949 \mathrm{X}$

(C) Medwell Journals, 2020

\title{
Case Study on Determining the Critical Production Rate for Bottom Water Coning in the Majed (EE-Pool) Reservoir
}

\author{
${ }^{1}$ Saad A. Balhasan and ${ }^{2}$ Daniel A. Michael \\ ${ }^{1}$ Department of Chemical and Petroleum Engineering, \\ ${ }^{2}$ American University of Ras Al Khaimah, Ras Al Khaimah, United Arab Emirates
}

\begin{abstract}
Inflow of bad water caused by the creation of non-uniform pressure conditions during petroleum production around a producing well bore may cause hydrocarbon production to gradually decrease and ultimately cease, trapping significant quantities of oil and gas in the petroleum reservoir. Production of this water along with commercial quantities of oil and gas causes an increase in the water cut over time, making the well gradually uneconomical leading to several management problems. This case study evaluates the characteristics of the EE-01 well located in the Majed EE-Pool reservoir in the Sirte Basin of Libya. The calculated optimum oil flow rate appropriate for economically feasible production to maximizing recovery is contrasted with the expected oil flow rate at the maximum productivity of the well. It is observed that the optimum oil flow rate bears an inverse relationship to the expected oil flow rate with an increase in the height of the perforations. It is recommended that the height of the perforation interval be changed to that which corresponds to the intersection of the optimum and expected oil flow rate lines in a chart of perforation interval height-vs-flow rate on which both the expected and optimum oil flow rates are plotted to both optimize petroleum production in EE-01 and maximize petroleum recovery from the Majed EE-Pool reservoir.
\end{abstract}

Key words: Water coning, well completions, reservoir engineering, water-drive mechanism, recommended, completions interval

\section{INTRODUCTION}

Water production is one of two recurring problems of critical concern in the oil and gas industry (Inikori et al., 2002). Water production into the well bore co-mingled with oil at an economic Water-Oil Ratio (WOR) cannot be reduced or shut off without affecting oil production from reservoirs. This problem is most pronounced in oil reservoirs with a water aquifer providing a strong pressure support system. Problems arise when water flows in to the oil well at a rate exceeding the economic WOR limit, producing little to no oil and negatively impacting well productivity, possibly leading to early abandonment of the well. It is estimated that on average oil companies produce three barrels of water for each barrel of oil, equivalent to almost 220 million barrels of water produced daily worldwide according to Schlumberger (Arslan, 2005) which entails a staggering cost of US $\$ 30-40$ billion worldwide (Guan et al., 2005). The cost of handling and disposing this unwanted water could have a negative impact on the economic life of the oil well for a given economic WOR limit. The environmental issues in connection with water production are another concern for oil companies. They must comply with strict environmental regulations regarding water treatment and disposal facilities. Excessive water production, called bad water, increases corrosion rates in the production system. Excess water production also kills oil wells by leaving a significant amount of oil trapped in the reservoir.

Good water is the water present in the reservoir that contributes critically to the production and extraction of hydrocarbons whereas bad water contributes little to hydrocarbon production but finds use in environments outside oil and gas exploration and production (Bailey et al., 2000). Water coning is a direct and in many cases, main cause of bad water production and is a result of the flow of fluid in the reservoir through the path of least resistance. The fluids in the reservoir have the tendency and ability to arrange themselves on top of each other in ascending order of their respective densities from top to bottom by gravity. Petroleum production from the well creates pressure gradients that increases the depth of the Gas-Oil Contact (GOC) and decrease the depth of the Water-Oil Contact (WOC) in the immediate vicinity of the well bore. The differences in densities of the respective fluids that cause the arrangement of the fluids in the reservoir discussed counter balance the non-uniform pressure conditions generated by petroleum

Corresponding Author: Saad A. Balhasan, Department of Chemical and Petroleum Engineering, American University of Ras Al Khaimah, Ras Al Khaimah, United Arab Emirates 
production. In order, therefore to delay the early break through of water and/or gas into the well the critical rate at which production must take place wherein the water coned around the well bore does not break through earlier than expected must be determined. At this critical production rate, the water cone is stable but is at a position of incipient break through. However, defining the conditions for achieving the maximum water-free and oil production rate is a difficult problem to solve. Engineers are often, therefore, faced with difficulties in predicting both this critical oil flow rate and the optimum length and position of the completions interval in order to minimize bad water production due to breakthrough of the water cone for economic petroleum production.

Three assessments-critical rate of oil production, cone breakthrough predictions and post-breakthrough well performance-are key in the resolution of a down hole coning problem in both vertical and horizontal wells. Calculating an optimum petroleum production rate involves several key reservoir rock and fluid parameters. As the WOC decreases in depth it is evident that the anisotropy of permeability plays an important role in the critical flow rate calculations, therefore, the permeabilities of each fluid in both the vertical $\left(k_{h}\right)$ and horizontal $\left(k_{v}\right)$ directions must be taken into account along with the respective fluid's viscosities and the distance between the water-oil or the gas-oil discontinuity and the well bore withdrawal point. The elimination of coning altogether can be aided by the shallower penetration of wells containing a water zone or by enhancement of the horizontal permeability. The ratio of the horizontal to the vertical flow in addition, can be increased through stimulation methods such as acidizing or fracturing techniques in the producing interval between the gas and water zones, permitting a more uniform rise of the water table. Once the water cone has broken through into the well, it is possible to shut in the well to allow the water and gas cones to stabilize, however, unless conditions for rapid attainment of gravity equilibrium are present, stabilization will not be satisfactory.

In this case study evaluating the EE-Pool (colloquially known as 'Majed') reservoir in Libya's Sirte Basin, the Chierici-Ciucci Model (Chierici et al., 1964) will be used to determine the optimum critical oil flow rate based on several reservoir parameters discussed above and engineering design parameters such as the distance between the WOC and the lowest point of the completions perforations and the optimum height of the perforation interval. To determine the breakthrough time of the water cone into the reservoir at a particular flow rate, the Sobocinski and Cornelius (1965) method will be used. The breakthrough time obtained from the Sobocinski and Cornelius (1965) method will be used along with the corresponding comparison between the respective optimum oil flow rates obtained from the
Chierici-Ciucci method and expected oil flow rates under unsteady-state Darcy flow conditions to observe and determine an economically and technically optimum oil production rate.

Geology of the sirte basin: A comprehensive geological description and characterization of the Sirte Basin and the Majed EE-Pool oil reservoir analyzed in this study is provided by Ahlbrandt (2001). Located at the Northern margin of the Messla structural high of the Sarir arm, the Majed EE-Pool reservoir in the Sirte Basin is contained in one dominant geological petroleum system known as the Sirte-Zelten total petroleum system (Ahlbrandt, 2001). The trap style of the Sirte Basin is dominantly structural across its extent with the rest of the petroleum traps classified as either stratigraphic or a combination of stratigraphic and structural traps (Clifford et al., 1980). The reservoir lithologies of the petroleum system are equally divided between clastic and carbonate formations which according to Montgomery (1994), contain proven reserves of 14.5Billion Barrels of Oil Equivalent (BBOE) and 10.6 BBOE, respectively. Harding (1984) however, shows that the Paleocene Zelten formation's carbonate formations contain approximately $8.5 \mathrm{BBOE}$, comprising about $33 \%$ of the total Estimate Ultimate Recovery (EUR). The basin is home to 237 hydrocarbon fields, 221 and 16 of which are oil and gas fields, respectively (Ahlbrandt, 2001).

The Sirte Basin is characterized by the large variety of reservoir rocks from which petroleum can be extracted ranging from sandstones and carbonates to fractured basement rocks. Harding (1984) notes that $42 \%$ of the petroleum found in this basin is located in Tertiary carbonate rocks with pre-tertiary clastic formations containing $58 \%$ of the total accumulations of petroleum. Oil can be produced from formations dating from the "Precambrian, Cambrian-Ordovician, Triassic through Lower Cretaceous, Paleocene and Eocene" (Ahlbrandt, 2001). Important reservoirs found in Cambrian-Ordovician sandstones, called Gargaf in the Western Sirte basin and referred to as the Amal group or the Hofra formation in the central part of the basin are responsible for oil production in 23 fields, 5 of which are giants. These include the Amal, Ragooba, Nafoora, Samah or Bel-Hadan and Waha fields (Ahlbrandt, 2001). At Amal and Ragooba, Roberts (1970) and Brennan (1992), respectively, note that natural fracture systems in these reservoirs enhance petroleum production. Amal, along with the Messla, Sarir and Abu Attifel reservoirs in the Sirte Basin also contain producing intervals made up of clastic strata of Nubian deposits, ranging from triassic, perhaps Late Jurassic to early cretaceous in age. These clastic producing intervals are also the major producing intervals in at least 72 fields in the Eastern Sirte Basin (Ahlbrandt, 2001). These are both alluvial and eolian 
continental sandstone deposits, although as Ambrose (2000) has noted, fan delta deposits are also present in key reservoirs in the upper sarir sandstone formation. The Nubian (Sarir) formation's variation in thickness (a maximum of up to $2500 \mathrm{~m}$, approximately $8224 \mathrm{ft}$ ) reflects the infilling of grabens that partly extends over some Cretaceous-era horsts and have formed "prolific structural/stratigraphic traps" (Ahlbrandt, 2001) such as the Sarir (Sanford, 1970; Lewis, 1990) and Messla fields (Ambrose, 2000). Lewis (1990) suggests that the Sarir field is itself a complex consisting of several smaller fields with Sarir $\mathrm{C}$ alone containing $6.5 \mathrm{BBOE}$ having an average porosity of $18-19 \%$ and an average permeability of approximately $200-300 \mathrm{mD}$. However, as documented by Abdulghader (1996), the main Sarir reservoir has an average porosity of $27.5 \%$. Along with the Cambrian-Ordovician sandstones in the Waha and Nafoora fields, carbonate formations aging from the Upper Cretaceous, Paleocene and Eocene eras also contain sizeable accumulations of petroleum and are important reservoir rocks in other fields such as Intisar, Beda, Defa, Haram, Zelten (Nasser) and Hofra (Belazi, 1989). Between the Intisar and Amal fields in Beda-Haram and in the Eastern Sirte Basin (Ghori and Mohammed, 1996), the presence of high sulfur (more than $3 \%$ ) indigenous heavy oil shows along with stratigraphic traps, nummulitic banks and dolomite zones in the Facha dolomite within the Eocene strata indicate a good target for petroleum exploration in the deeper parts of both onshore and offshore grabens (Abugares, 1996). In general, however, the majority of the reservoirs of the Sirte Basin including Majed, consist of petroleum accumulations found in sandstone and/or carbonate reservoir rocks, some with natural fracture systems that enhance petroleum production that may include both sandstone and carbonate production intervals common between many of the reservoirs indigenous to the basin.

Production optimization in the Majed (EE-Pool) reservoir: To predict the breakthrough time and the critical oil flow rate as a function of various reservoir and design parameters, the Sobocinski and (Cornelius, 1965) and the (Chierici et al., 1964) models will respectively be used. Figure 1 shows the model schematic used in the Chierici-Ciucci method which uses a potentiometric model to predict coning behavior in oil wells. The results of their work are presented in dimensionless graphs that take into account the vertical and horizontal permeability.

Using this method, the critical oil flow rate can be determined as a function of the height of the perforations, the distance between the bottom of the perforations and the top of the water cone and the height of the production interval. Sobocinski and Cornelius (1965) developed a correlation for predicting water breakthrough time based

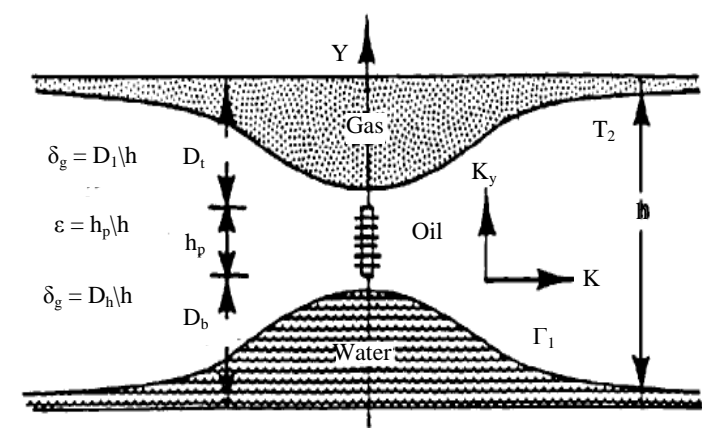

Fig. 1: The model schematic used in the Chierici-Ciucci method

on laboratory data and modeling results. The researchers correlated the breakthrough time with two dimensionless parameters the dimensionless cone height and the dimensionless break through time which will be used in the (Chierici et al., 1964) to determine the corresponding oil flow rate that causes the observed breakthrough time.

\section{MATERIALS AND METHODS}

Methodology for the Chierici-Ciucci method: The steps used in the Chierici-Ciucci method (Chierici et al., 1964) to obtain the critical oil flow rate and an optimum production interval height are explained as follows. To obtain the critical oil flow rate for a particular production interval gross thickness, the following steps must be taken:

The effective dimensionless radius $\mathrm{r}_{\mathrm{De}}$ must be determined which is the first dimensionless parameter that was used to correlate result of the case that will be interdicted must be determined:

$$
\left(\mathrm{r}_{\mathrm{De}}=\frac{\mathrm{r}_{\mathrm{e}}}{\mathrm{h}} * \sqrt{\frac{\mathrm{k}_{\mathrm{h}}}{\mathrm{k}_{\mathrm{v}}}}\right.
$$

Next, the dimensionless perforated length the ratio between the height of the perforation interval to the production zone thickness must be determined:

$$
\varepsilon=\frac{h p}{h}
$$

The water coning ratio another dimension less quantity must be determined next:

$$
\delta \mathrm{w}=\frac{\mathrm{Dp}}{\mathrm{h}}
$$

The two dimensionless parameters calculated previously ( $\varepsilon$ and $\delta_{w}$ ) are used to determine the 


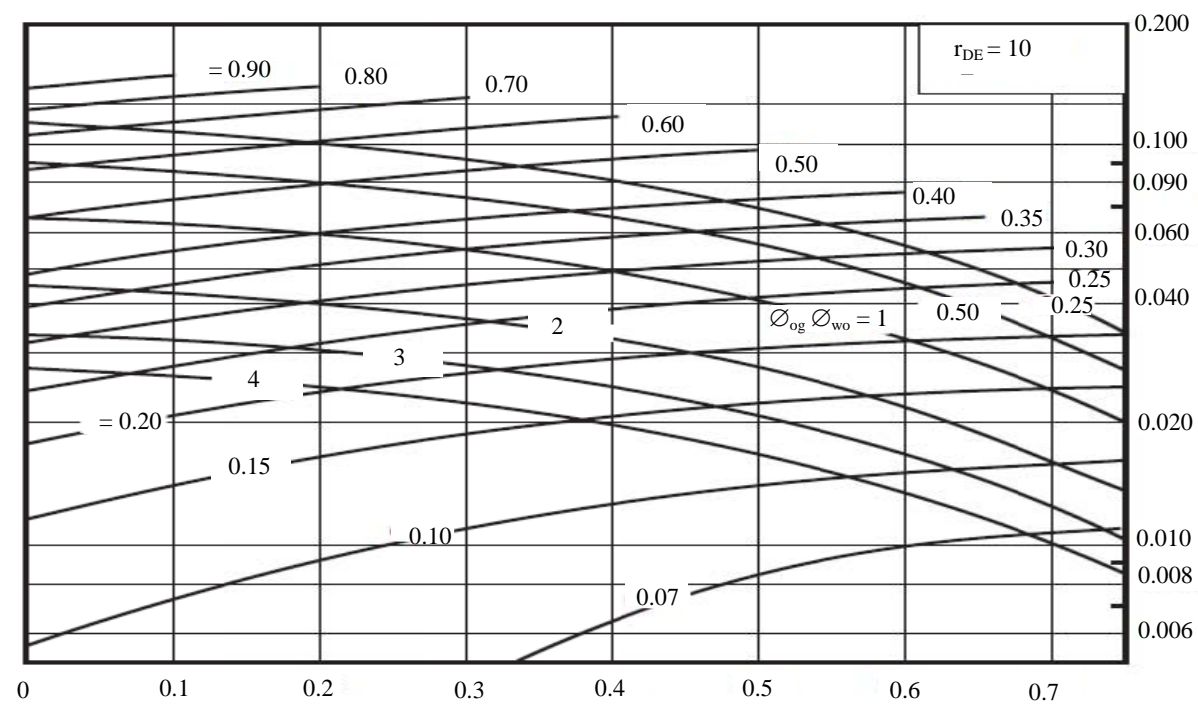

Fig. 2: Chart of dimensionless radius values from Ahmed (2006)

dimensionless water function $\left(\Psi_{\mathrm{w}}\right)$ from the graph in Fig. 2. This chart is shown for $r_{\mathrm{De}}=5$ but several charts exist for several values of $r_{D e}$. The values obtained from Eq 1-3 are applied in the equation given below to arrive at the critical oil flow rate:

$$
\mathrm{Q}_{\mathrm{ow}}=0.492 * 10^{-4 *} * \frac{\mathrm{h}^{2}(\rho \mathrm{W}-\mathrm{\rho o})^{*}\left(\mathrm{k}_{\mathrm{ro}}{ }^{*} \mathrm{k}_{\mathrm{h}}\right)^{*} \Psi_{\mathrm{w}}}{\mathrm{Bo}^{*} \mu \mathrm{o}}
$$

where, $Q_{o w}$ is the critical oil flow rate in STB/day and are the water and oil densities, respectively in $\mathrm{lb} / \mathrm{ft}^{3}$ is the dimensionless water function, $\mathrm{k}_{\mathrm{h}}$ is the horizontal permeability in $\mathrm{mD}$, Bo is the crude oil formation volume factor in res. bbl/STB and $\mathrm{mo}$ is the viscosity of the crude oil in $\mathrm{cp}$.

To obtain the optimum perforation interval for an assumed perforated interval, the following steps must be taken:

- Assume the length of the perforation intervals

- Calculate the dimensionless perforated length

- Select the fitted curves that corresponds to $\mathrm{rDe}$, interpolate if necessary and enter the working charts with on the $\mathrm{x}$-axis and move vertically to the calculated ratio

- Calculate the distance from the WOC to the bottom of the perforation for every interval:

$$
\mathrm{D}_{\mathrm{p}}=\mathrm{h}-\mathrm{h}_{\mathrm{p}}
$$

Using the optimum dimensionless function opt in Eq. 4 calculate the maximum allowable oil-flow rate $Q_{\text {ow }}$. Repeat steps 1 through 5 .
The values of $Q_{\text {ow }}$ at different assumed perforated intervals should be compared with those obtained from flow-rate equations, e.g., Darcy's equation, using the maximum drawdown pressure.

Methodology for the Sobocinski-Cornelius method: Critical flow rate calculations frequently show low production rates that are not economically efficient cannot be imposed on production wells. However, if a well produces above its critical rate, the cone will break through after a given time interval. Therefore, the Sobocinski-Cornelius method will be employed in determining breakthrough time for the encroaching water. Sobocinski and Cornelius (1965) developed a correlation for predicting water break through time based on laboratory data and modeling results. The authors correlated the breakthrough time with two dimensionless parameters the dimensionless cone height and the dimensionless breakthrough time defined by the expressions shown below along with the steps outlining the determination of key parameters required in the calculation of break through time: calculate the dimensionless cone height $\mathrm{z}$ using this equation:

$$
\mathrm{Z}=0.492 * 10^{-4} *\left(\frac{(\rho \mathrm{w}-\rho \mathrm{o}) \mathrm{k}_{\mathrm{h}} \mathrm{h}\left(\mathrm{h}-\mathrm{h}_{\mathrm{p}}\right)}{\mu_{\mathrm{o}} \mathrm{B}_{\circ} \mathrm{Q}_{\mathrm{o}}}\right)
$$

Calculate the dimensionless breakthrough time $\left(t_{D}\right)$ by using this equation:

$$
\left(\mathrm{t}_{\mathrm{D}}\right)_{\mathrm{BT}}=\left(\frac{4 \mathrm{z}+1.75 \mathrm{z}^{2}-0.75 \mathrm{z}^{2}}{7-2 \mathrm{z}}\right)
$$




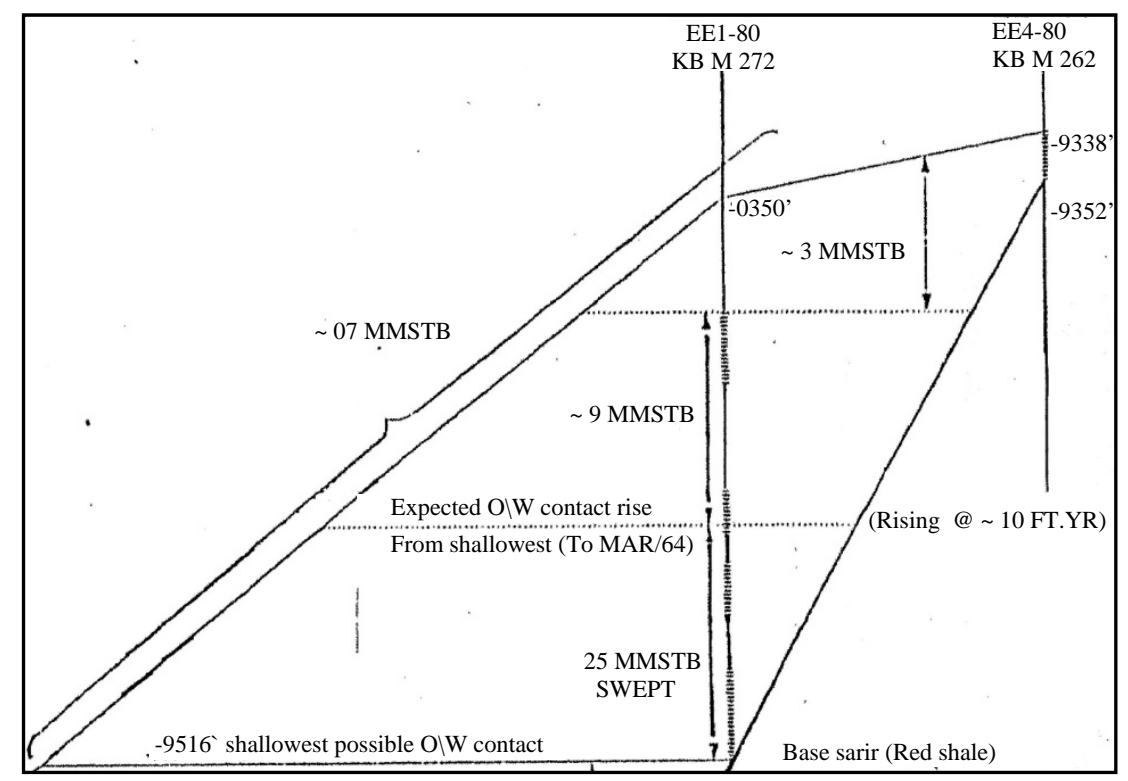

Fig. 3: Schematic geological cross-section of underlying stratigraphy and arrangement of wells including EE-01 at the EE-Pool (Majed) reservoir

Predict the time to water cone breakthrough from the calculated value of the dimensionless breakthrough time $\left(\mathrm{t}_{\mathrm{D}}\right)_{\mathrm{BT}}$ by using this Eq. 8 :

$$
\mathrm{t}_{\mathrm{BT}}=\frac{20325 \mu_{0} \mathrm{~h} \phi(\mathrm{tD}) \mathrm{BT}}{(\rho \mathrm{W}-\rho \mathrm{o}) \mathrm{k}_{\mathrm{v}}\left(1+\mathrm{M}^{\alpha}\right)}
$$

Where:

z : The dimensionless cone height

$\mathrm{k}_{\mathrm{h}} \quad$ : The horizontal permeability

$\mathrm{k}_{\mathrm{v}} \quad$ : The vertical permeability

$\mathrm{h}$ : The thickness of the oil column

$h_{p} \quad:$ The height of the perforation interval

Q。 : The oil production rate

$\left({ }_{\mathrm{Td}}\right)_{\mathrm{BT}}$ : The dimensionless time at water cone breakthrough

$t_{B T}:$ The time to breakthrough of the water cone

$\varnothing \quad$ : The porosity of the producing interval

$\mu_{0} \quad:$ The viscosity of the crude oil $\rho w$ and po are the water and oil densities, respectively in $\mathrm{lb} / \mathrm{ft}^{3}$

M : The water-oil Mobility and is defined by:

$$
\mathrm{M}=\left[\frac{\left(\mathrm{k}_{\mathrm{rw}}\right) \mathrm{sor}}{\left(\mathrm{k}_{\mathrm{ro}}\right) \mathrm{swc}}\right]\left[\frac{\mu_{\mathrm{o}}}{\mu_{\mathrm{w}}}\right]
$$

With:

$\left(\mathrm{k}_{\mathrm{rw}}\right) \mathrm{s}_{\mathrm{or}} \quad$ : The relative permeability of water at residual oil saturation

$\left(\mathrm{k}_{\mathrm{ro}}\right)$ swc : The relative permeability of oil at connate water saturatio $\left(\mathrm{k}_{\mathrm{rw}}\right) \mathrm{s}_{\mathrm{wp}} \mathrm{n}$, for $\mathrm{M}<1$ and for $\mathrm{M}>1$

Application in case study: The (Chierici et al., 1964) and the (Sobocinski and Cornelius, 1965) methods will

Table 1: Relative permeability data for the Majed (EE-Pool) reservoir

\begin{tabular}{lccrc}
\hline $\mathrm{S}_{\mathrm{w}}$ & $\mathrm{k}_{\mathrm{r}}$ & $\mathrm{k}_{\mathrm{w} w}$ & $\mathrm{k}_{\mathrm{r}} / \mathrm{k}_{\mathrm{rw}}$ & $\mathrm{f}_{\mathrm{w}}$ \\
\hline 0.335 & 0.7000 & 0.0000 & - & 0.000 \\
0.395 & 0.3939 & 0.0212 & 18.6000 & 0.050 \\
0.475 & 0.1646 & 0.0624 & 2.6000 & 0.290 \\
0.485 & 0.1444 & 0.0687 & 2.1000 & 0.340 \\
0.518 & 0.0972 & 0.0879 & 1.1000 & 0.490 \\
0.540 & 0.0731 & 0.1017 & 0.7200 & 0.590 \\
0.555 & 0.0598 & 0.1113 & 0.5400 & 0.660 \\
0.580 & 0.0425 & 0.1278 & 0.3300 & 0.760 \\
0.610 & 0.0279 & 0.1482 & 0.1900 & 0.850 \\
0.660 & 0.0139 & 0.1836 & 0.0700 & 0.940 \\
0.700 & 0.0083 & 0.2131 & 0.0400 & 0.960 \\
0.740 & 0.0052 & 0.2436 & 0.0200 & 0.980 \\
0.780 & 0.0032 & 0.2749 & 0.0100 & 0.990 \\
0.820 & 0.0018 & 0.3071 & 0.0005 & 0.995 \\
0.860 & 0.0000 & 0.3400 & 0.0000 & 1.000 \\
\hline
\end{tabular}

now be applied to determine a critical oil flow rate and an optimum perforation interval thickness for the EE-01 well located in the Majed reservoir. A cross section of the reservoir along with a chart of the relative permeability data for the EE-Pool reservoir is provided in Fig. 3. Table 1 provides the data set for the relative permeability and Table 2 provides the design data for the EE-01 well in the EE-Pool reservoir. These data sets will be used along with the data provided on the operator's design of the well to optimize production rates and perforated interval thickness.

The expected oil flow rate is obtained from the equation used to calculate the production rate for an unsteady-state Darcy-type flow regime with a radial flow geometry as described by Ahmed (2006). This oil flow rate will be compared with the oil flow rate obtained from the above two methods for each assumption of 
J. Eng. Applied Sci., 15 (4): 925-931, 2020

Table 2: Design parameters of well EE-01

\begin{tabular}{lrl}
\hline Parameters & Values & Units \\
\hline$\mu_{\circ}$ & 0.143 & $\mathrm{cp}$ \\
$\mathrm{h}$ & 182 & $\mathrm{ft}$ \\
$\mathrm{h}_{\mathrm{p}}$ & 28 & $\mathrm{ft}$ \\
$\mathrm{D}_{\mathrm{p}}$ & 65 & $\mathrm{ft}$ \\
$\mathrm{r}_{\mathrm{w}}$ & 65 & $\mathrm{lb} / \mathrm{ft}^{3}$ \\
$\mathrm{r}_{\mathrm{o}}$ & 45 & $\mathrm{lb} / \mathrm{ft}^{3}$ \\
$\mathrm{r}_{\mathrm{g}}$ & 6.12 & $\mathrm{lb} / \mathrm{ft}^{3}$ \\
$\mathrm{~B}_{\circ}$ & 1.52 & $\mathrm{bbl} / \mathrm{STB}$ \\
$\mathrm{k}_{\mathrm{h}}$ & 250 & $\mathrm{mD}$ \\
$\mathrm{k}_{\mathrm{v}}$ & 100 & $\mathrm{mD}$ \\
$\mathrm{R}_{\mathrm{e}}$ & 1100 & $\mathrm{ft}$ \\
\hline
\end{tabular}

perforation interval thickness with a chart of the perforation interval thickness assumed vs the two oil flow rates. The intersection of the two curves of the expected and optimum oil flow rates will provide an optimum perforation depth and a critical oil flow rate below which the water cone will not break through into the well bore at the subsequently calculated time period.

\section{RESULTS AND DISCUSSION}

The results of applying the equations listed in the above sub-section from 1-8 to calculate both the optimum and expected oil flow rates and an optimum perforation interval are listed in Table 3 the variables shown in the same table possess the same meaning and units as that which is elucidated in the methodology of the Sobocinski-Cornelius method(1965) earlier in this study. As we can see, increasing the perforation interval thickness over assuming different perforation interval thicknesses increases the expected oil flow rate but decreases the optimum oil flow rate. Thus an inverse relationship is borne between the two quantities, leading to an opportunity to derive the thickness of the perforation interval by examining the intersection point of the two curves in order to produce an optimum perforation interval thickness which is elucidated in Fig. 4. The viscosity of the formation water was taken to be $0.25 \mathrm{cp}$. As shown in Fig. 4, the intersection of the expected and optimum oil flow rates occurs at approximately $3200 \mathrm{STB} /$ day with a corresponding perforation interval thickness of approximately $55 \mathrm{ft}$.

This method of graphical interpretation can be employed with an approximate degree of accuracy to determine the optimum oil flow rate but accurate calculations can be done using the Sobocinski and Cornelius method (1965) to determine the optimum height of the perforation intervals to determine the critical oil flow rate. Calculations done for an optimum oil flow rate of $3200 \mathrm{STB} /$ day yielded a breakthrough time of 1859.4 days, corresponding to 5.09 years.
Table 3: Results obtained for optimization calculations for well EE-01

\begin{tabular}{llllrlr}
\hline $\mathrm{h}_{\mathrm{v}}$ & $\mathrm{D}_{\mathrm{n}}$ & $\delta_{\mathrm{w}}$ & $\Psi_{\mathrm{ant}}$ & $\mathrm{Q}_{\mathrm{nnt}}$ & $\mathrm{Q}_{\mathrm{ax} \mathrm{n}}$ & $\mathrm{t}_{\mathrm{BT}}$ \\
\hline 30 & 152 & 0.835 & 0.164 & 2799.27 & 1754 & 1044.6 \\
50 & 120 & 0.659 & 0.130 & 3150.69 & 2924 & 1148.6 \\
70 & 112 & 0.615 & 0.140 & 3393.05 & 4094 & 362.0 \\
90 & 92 & 0.506 & 0.099 & 2399.37 & 5263 & 176.5 \\
110 & 72 & 0.396 & 0.078 & 1890.41 & 6433 & 92.9 \\
\hline
\end{tabular}

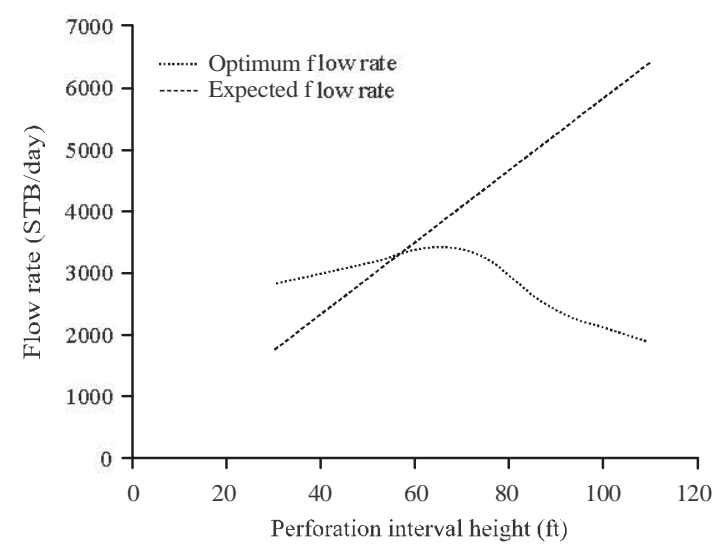

Fig. 4: Optimum and expected production rates with respect to height of perforation interval

\section{CONCLUSION}

The perforated interval in well EE-01 of the Majed (EE-Pool) reservoir has been provided as $28 \mathrm{ft}$ of $182 \mathrm{ft}$ of the total producing interval in the reservoir. In the calculations listed in the results and analysis section of this case study, it has been proven that up to the optimum perforation interval height calculated, the break through time of the water cone in the immediate vicinity of the well increases with an increase in production and then begins to decrease with further increases in the height of the perforated interval. This proves that the current perforation interval height of EE-01 is not optimized for maximum recovery and optimum production. While the expected oil flow rate increases with an increase in the height of the perforation interval, the optimum flow rate decreases as it is shown that the break through time also decreases. The optimum height of the perforation interval, therefore is calculated as approximately $55 \mathrm{ft}$ which yields an optimum production rate of approximately $3200 \mathrm{STB} /$ day.

\section{ACKNOWLEDGEMENTS}

The researchers would like to thank the Arabian Gulf Oil Company (AGOCO) of Libya for providing the necessary data for analysis of this case study. The researchers would also like to thank the American University of Ras Al Khaimah in the Emirate of Ras Al Khaimah, United Arab Emirates for providing the opportunity to publish this case study. 


\section{REFERENCES}

Abdulghader, G.S., 1996. Sedimentology and reservoir heterogeneities of the Nubian formation, Southeastern Sirt Basin, Libya. Geol. Sirt Basin Amsterdam Elsevier, 2: 223-250.

Abugares, Y.I., 1996. Sedimentology and hydrocarbon potential of the Gir Formation, Sirt Basin, Libya. Geol. Sirt Basin Amsterdam Elsevier, 2: 31-64.

Ahlbrandt, T.S., 2001. The Sirte Basin Province of Libya: Sirte-Zelten Total Petroleum System. US Department of the Interior, US Geological Survey, Denver, Colorado,

Ahmed, T., 2006. Reservoir Engineering Handbook. 3rd Edn., Gulf Professional Publishing, Ellservier, Burligton, MA, USA., pp: 190-198.

Ambrose, G., 2000. The geology and hydrocarbon habitat of the Sarir Sandstone, SE Sirt Basin, Libya. J. Pet. Geol., 23: 165-192.

Arslan, O., 2005. Optimal operating strategy for wells with downhole water sink completions to control water production and improve performance. P.hD. Thesis, Louisiana State University, Baton Rouge, Louisiana.

Bailey, B., M. Crabtree, J. Tyrie, J. Elphick, F. Kuchuk, C. Romano and L. Roodhart, 2000. Water control. Oilfield Rev., 12: 30-51.

Belazi, H.S., 1989. The geology of the Nafoora oilfield, Sirte Basin, Libya. J. Pet. Geol., 12: 353-366.

Brennan, P., 1992. Raguba Field-Libya Sirte Basin. In: Structural Traps: Tectonic Fold Traps, Beaumont, E.A. and N.H. Foster (Eds.). American Association of Petroleum Geologists, Tulsa, Oklahoma, pp: 267-289.

Chierici, G.L., G.M. Ciucci and G. Pizzi, 1964. A systematic study of gas and water coning by potentiometric models. J. Pet. Technol., 16: 923-929.

Clifford, H.J., R. Grund and H. Musrati, 1980. Geology of a Stratigraphic Giant: Messla Oil field, Libya. In: Giant Oil and Gas Fields of the Decade: 1968-1978, Halbouty, M.T. (Ed.). American Association of Petroleum Geologists, Tulsa, Oklahoma, USA., ISBN: 9781629811840, pp: 507-524.
Ghori, K.A.R. and R.A. Mohammed, 1996. The application of petroleum generation modelling to the eastern Sirt Basin, Libya. Geol. Sirt Basin Amsterdam Elsevier, 2: 529-540.

Guan, L.L., Y. Du and Z. Wang, 2005. Water injectivity-What we have learned in the past 30 years. Proceedings of the Canadian International Conference on Petroleum, June 7-9, 2005, Petroleum Society of Canada, Calgary, Alberta, pp: 1-11.

Harding, T.P., 1984. Graben hydrocarbon occurrences and structural style. AAPG. Bull., 68: 333-362.

Inikori, S.O., A.K. Wojtanowicz and S.S. Siddiqi, 2002. Water control in oil wells with downhole oil-free water drainage and disposal. Proceedings of the SPE Annual International Technical Conference and Exhibition, September 29-October 2, 2002, San Antonio, Texas, pp: 1-10.

Lewis, C.J., 1990. Sarir Field. In: Structural Traps: Traps Associated with Tectonic Faulting, Beaumont, E.A. and N.H. Foster (Eds.). American Association of Petroleum Geologists, Tulsa, Oklahoma, USA., ISBN: 9780891815815, pp: 253-267.

Montgomery, S., 1994. Sirte Basin, North-Central Libya: Prospects for the Future. Vol. 11, Petroleum Information Corporation, Littleton, Colorado, Pages: 94.

Roberts, J.M., 1970. Amal Field, Libya. In: Geology of Giant Petroleum Fields, Halbouty, M.T. (Ed.). American Association of Petroleum Geologists, Tulsa, Oklahoma, USA., ISBN: 9780891812883 , pp: 438-448.

Sanford, R.M., 1970. Sarir Oil Field, Libya-Desert Surprise. In: Geology of Giant Petroleum Fields, Halbouty, M.T. (Ed.). American Association of Petroleum Geologists, Tulsa, Oklahoma, USA., ISBN: 9780891812883 , pp: 449-476.

Sobocinski, D.P. and A. Cornelius, 1965. A correlation for predicting water coning time. J. Pet. Technol., 17: 594-600. 